\title{
Local Political Leadership in Urban Governance and Public Administration Modernisation: The Role of the Mayor and Councillors in a Spanish Municipality (1979-2007)
}

\author{
Ángel IgLesias AlONSO \& MANUEL ViLLORIA MENDIETA
}

\begin{abstract}
Implementing urban governance strategies to improve local democracy and to regulate local economic growth is an important determinant of effective local administrative change and performance. The underlying hypothesis adopted here is the assumption that the adoption of urban governance processes requires political leadership. It inevitably results in the introduction of innovations within the administrative apparatus in order to improve its performance. Indeed, understanding the interaction between these three aspects (political leadership, urban governance, and administrative modernisation) is of fundamental importance for the effectiveness of most, if not all, policy interventions directed at the introduction of democratic innovations and public administration modernisation initiatives in local governments. To bring out the importance of those interactions, case study ${ }^{1}$ research is used.
\end{abstract}

KEYWORDS: $\bullet$ local government $\bullet$ urban governance $\bullet$ administrative modernisation $\bullet$ public policy $\bullet$ political leadership $\bullet$ Spain

CORRespondence AdDress: Ángel Iglesias Alonso, Ph.D., Faculty of Law and Social Sciences, University Rey Juan Carlos, Artilleros s/n - 28032 Madrid, Spain, email: angel.iglesias@urjc.es. Manuel Villoria Mendieta, Ph.D., Faculty of Law and Social Sciences, University Rey Juan Carlos, Artilleros s/n - 28032 Madrid, Spain, email: manuel.villoria@urjc.es. 


\section{Urban Governance, Administrative Modernisation, and Local Political Leadership}

The globalisation process catalyses local governments so that the latter become active innovators in public management in efforts to redeem and legitimise governance through democratic processes. In fact, the legitimacy of the city rests "in the form of government and in the story it promises - non-political, efficient, and responsive government" that both facilitates community involvement and delivers the needed and desired services (Nalbandian, 1999). To this end, local political elites adopt urban governance processes that inevitably result in the introduction of innovations with the desire both to expand the representative democracy and to improve its performance in delivering public services through political and managerial leadership (Berg, Rikke and Nirmala Rao, 2005). Indeed, understanding the interaction between these aspects is of fundamental importance for the effectiveness of most, if not all, policy interventions directed at the modernisation of local public administration.

As it is understood here, urban governance is a particular dimension of the wider concept of governance or, more specifically, one of its territorial manifestations (Canales, 2001). Within local territory, two apparently counterpoised trends coincide, observable above all in cities. They have an impact on their governance: on the one hand, there are demands derived from the new forms of the reproduction of capital, and, on the other hand, there are local traditions linked to specific local problems. The functionality of the local political system needs to respond to these trends through public action removed from the technocratic purism that implies isolation. Instead, there needs to be participation of various actors with their interests in the local territory.

In the urban sphere, city governance, being a regulation model, is derived from the globalisation and decentralisation processes that lead to the re-politicisation of the local level (Brugué and Gomá, 1998, Bäck, Heinelt and Magnier, 2006). This situation implicitly leads the change from local governance to administering the interaction of a set of organised actors who, to maximise local resources, act in a network in which political-administrative actors sometimes act as initiators and moderators of that interaction. The hierarchical relations, inseparable from the management model, become interaction relations that enable civil society organisations to become co-producers of local public services.

All this means that local governments evolve from bureaucratic management of public services to governing the city through implementing their own initiatives and exercising political leadership (Benington, 1998). This constitutes a change in the functions of the political and administrative elites that are no longer administrators of a centralised system, but instead they become promoters of local 
development in an increasingly complex environment into which new actors are incorporated.

In this sense, city governance involves a change from the logic of local administration (understood as the management of undifferentiated public services) to another type of administration responsible for its citizen welfare. To achieve this objective, the local administration is impelled to innovate and modernise with the aim of managing the resources of the territory in order to resolve (in conjunction with other actors and through imaginative methods of collaboration) the specific problems of its citizens, making innovation and dynamism compatible with the democratic control of market forces. The responses to the processes, derived from the intersection of the frontiers between the public and private sectors, the interdependencies thus produced among the organisations previously included in the two sectors, and the need to base authority not on hierarchies, but instead on negotiations, consensus, and cooperation among multiple sets of organisations to formulate and implement local public policies, constitute structural elements of local governance. Understood in this way, urban governance is simply the inclusion of local government institutions in wider processes for the formulation and implementation of public policies. This incorporation may signify the blurring of the public power into other interests or its establishment as the promoter or coordinator from the spheres of political power of the set of actors with local interests (Stoker, 1998). The local political powers converse with local groups and organisations that demand recognition of their influence to intervene in the affairs that directly concern them. They do not concentrate on isolated interventions, but instead they create links with different degrees of permanence, with groups that have an interest in the city, and thus local government is required to become involved in inter-organisational and intergovernmental relations, and with civil society (Bowers and Wilburg, 2000).

From all of the above-mentioned, it is easy to conclude that governance and the modernisation process, which is dependent on it, are associated with a complicated relation. Thus, the process causes progress to be made towards the governance model with implications for the local political-administrative apparatus, for its products in terms of public policies and services, and for the quality of municipal democracy. To this effect, the process of administrative innovation becomes a variable that influences governance, modulated by local conditions not only politically, but also socio-economically and culturally. It is influenced by social capital (Putnam, 1993), and by the material, personnel, and financial resources of its institutions of government and administration. Administrative innovation usually involves the process of change in the core of the administrative apparatus. This is the process in which there is room for conflict settlement, and for seeking consensus through negotiations in which elements such as power, influence, and resources become evident. Administrative 
innovation is, therefore, a political process that adopts its own dynamics on the basis of political initiatives. It is produced in the context of the specific political and administrative activities of an administrative institution. Thus, the institutional context becomes a key variable in the analysis process. In this regard, and contrary to the idea of the loss of centrality of the public sector in favour of the market, the locus of political control may remain within the local government despite the new actors that are incorporated into the public decision-making process. This means accepting that governance has an important political dimension and that its effects and impacts cannot be separated from the dominant political values and political leadership.

A governance study must make reference to the leadership that is particularly important in the sphere of local government in the cities where other resources, including institutional and empowerment resources, are limited in relation to the challenges to which they must respond. Political leadership is of interest in governance insofar as its exercise involves interactions with followers or other actors. Then the existence of systemic factors does not necessarily lead to governance process development. Their causes are to be found in political action constituted on the basis of the exercise of political leadership. This is because in the fragmented contexts that characterise cities, political leadership becomes one of the principal - if not the principal - elements of urban governance. Without a doubt, this exercise of leadership is modulated by institutional factors such as the strong mayor model that is configured in the Spanish local government system as long as he or she enjoys a majority in plenary sessions.

Without doubt, the public sector leadership has to do with politics and power. The literature on political leadership in the local sphere places emphasis upon personal characteristics (Gleason, 1970, Kessner, 1989, Flanagan, 2004) or upon institutional aspects (Pressman, 1972, Svara, 1990, 2009, Copus, 2006). There are also normative studies regarding the best use of power in order to manage (Pfeffer, 1992, Haus and Sweeting, 2006). The study of leadership, therefore, emphasises two dimensions: personal and institutional. In addition to the complex of personal and contextual circumstances, such as personality, political experience, institutional factors, and local opportunity structures, leadership also depends on the capacity to take risks. Local public administration overlaps with the political sphere, and politicians must play an active role, formulating the strategic objectives of the local government and administration, and controlling their results with regard to strategic affairs (Haus and Sweeting, 2006, Gissedanner, 2004). However, few empirical case studies have been carried out. Therefore, in this paper, we analyse the Spanish experience that we qualify as relevant. Since the return to a democratic regime, local governments have taken on new roles both in fostering democracy and in providing a range of public services by introducing management innovations within the previous bureaucratic administrative culture. 
The study addresses two issues. The first one deals with the mayoral leadership style to implement initiatives for local governance. And the second one has to do with the modernisation of the administrative apparatus for efficient and effective local policies.

\section{Political Leadership in Alcobendas (1979-2007): The Context and its Dynamics}

Alcobendas is located some 12 miles away north of Madrid. With 100,000 inhabitants, the once working-class city has been transformed into a modern one over the last 30 years. This transformation coincided with the political leadership of Caballero, the Mayor who took office after the first democratic local elections (after the authoritarian Franco regime). Caballero remained in power by winning successive elections until his retirement in 2007. From the moment he first took office, he developed political and managerial leadership that coincided with the vision of the city, accompanied by the absence of professionalism derived from a corporate (bureaucratic) vision of the administrative apparatus. In Alcobendas, the political leadership exercised by the Mayor was a critical factor in the process of change. As a result, some of the characteristics of this leadership require examination.

There are contextual factors that facilitate the leadership model of the Mayor José Caballero (the city is territorially and socially unstructured). Successive mandates enable him to accumulate political capital from which he exercises pragmatic leadership. Caballero exercises strong, proactive leadership in his party and in the municipal government. He is not a professional politician in terms of harbouring ambitions beyond the municipality. Thus, he concentrates all his efforts on the city. He has a project for the city in which:

a. On the basis of his own initiatives, he achieves the implication and mobilisation of diverse actors, who have their own interests, for the development of the city. Such initiatives include the network of local associations and also property developers with the aim of creating public value on the basis of a public resource (for example, the transformation of a plot of land belonging to the Town Hall into the Alcobendas 2000 Urban Project that creates and distributes value). Urban governance demands leadership capable of working horizontally (John, 2001). The personal characteristics of the Mayor of Alcobendas provide him with the capacity to establish cooperative relations with economic interests without neglecting social affairs and without corruption scandals. He catalyses the energies and initiatives of other public and private actors capable of giving the city its own identity. 
b. Among the Mayor's followers are both political appointees and specialist technical staff who are in favour of the change in administrative culture and of modernisation. The door is open to recent graduates who gain managerial posts as well as to managers who have private sector experience. The process impulse is maintained through training.

c. He achieves investment from the CAM (Autonomous Community of Madrid) for urban infrastructure, public facilities and housing, and he even manages to mobilise the politicians from the surrounding cities.

d. He can see new possibilities for the city by generating expectations among political and managerial appointees for the achievement of those possibilities. In some town planning projects, his ideas cause surprise among some councillors, but not resistance.

e. During his mandate, there was an absence of corruption. Similarly, he did not pursue personal gain and wealth through the exercise of his office.

f. Being a Mayor, he was accessible to citizens. He also attempted to include citizens in the governance of the city.

g. He exercised control over the association sphere through institutional support.

Furthermore, leadership is exercised through both a discourse and activities. The leadership of the Mayor of Alcobendas may be analysed by studying his discourse and activities (Drake, 1995).

\subsection{The Mayor's Discourse ${ }^{2}$}

A set of beliefs, values, perceptions, preferences, and motivations can be identified through the Mayor's discourse. The Mayor's beliefs are reflections on socialisation and personal experience. Since the beginning of the clandestine political activity in 1966, he has shown a commitment to ideological values that demonstrate a personal conviction, namely that politics is an instrument to avoid inequalities and to transform society, and, through long-term projects, to create a vision for the city in which sustained economic growth is combined with social structuring. He defines himself as a self-made man. In 1976, he established the PSOE (Spanish Socialist Party) local group together with six other members. He is thus a Mayor with deep roots in the community. ${ }^{3}$ This helps his personality to be more important than the party to which he belongs. He represents efficiency attributed to him by the media and by the city's opinion leaders.

The Mayor maintains the "city dreams"4 (understood as the knowledge he has of Alcobendas) supported by his years of residence in the city and by his political activism under the previous regime. 


\subsection{The Mayor's Activities}

Being a councillor, he strove to encourage citizen participation in the sphere of government action during the first democratic government. He argued that political activity should be located where the real problems could be found, i.e., at the neighbourhood level.

He is a visible Mayor ${ }^{5}$ (which is in itself a form of accountability), and the objectives and methods, established to make his vision a reality, are based on an incremental pragmatism. He is the Mayor interested in a) creating networks, and in b) implementing the agreements that allow taking maximum advantage of public and private resources. ${ }^{6}$

This means that he shows the ability to maintain a dialogue with those who have different interpretations of the city and to balance the tension between actors by acting as an intermediary between the needs of citizens and local possibilities. In the same way, he has an important influence on local public opinion. This explains why, since the beginning of his mandate, he had maintained close relations with local associations thereby stimulating the implementation of informal networks, creating the potential for consensus in specific public policies.

On the basis of the above information, the efficient institutional leadership of the Mayor is supported by two pillars. On the one hand, there is the Mayor as an entrepreneur in the Schumpeterian sense of the term, but on the other hand, there is the Mayor as the incarnation of the social figure of a "politician", the person who is immersed in politics as a vocation in the Weberian sense ${ }^{7}$. Viewed from the perspective of the Schumpeterian theory of entrepreneur as a metaphor for the Mayor, the latter plays important roles by proposing and negotiating agreements with private business interests. And when being a representative of the city, he promotes it in other regions and countries to attract new industries by lobbying at regional and national government levels, seeking new investments, subsidies and aid from different levels of government, including the European Union, with the aim of generating local projects and initiatives that act as catalysts for local industry. The Mayor is considered as an entrepreneur of the city, a person able to create coalitions of interests and to provide opportunities for the city, which reduces the impact of party politics. His leadership influences the level of citizen confidence as well as external investors.

The Mayor represents a model of promotional leadership capable of agglutinating diverse coalitions (public-public and public-private) through their complementation and the optimisation of their effectiveness. It is necessary to underline the Mayor's role in the creation of a network of public and private actors around a variety of projects (e.g., the Science Museum). The Mayor is interested 
in all what is of interest to the city: from the poverty and living standards of the least well-off sectors of the population to the projects that reap prestige. His connections with the associations, which do not exclusively pursue economic interests, have proven to be essential. Similarly, the Mayor exercises the leadership that is open to society linked to certain values and based on common objectives aimed at improving the city through diverse projects.

Moreover, his leadership is creative in so far as it is capable of mobilising sectors of the local community for collective action (the Youth Plan), demonstrating his capacity for creativity and coordination. The key to Caballero's leadership is regeneration strategy development with regard to property development (through consensus among local elites) in order to promote economic development and social progress, and with a capacity to mobilise the groups that participate in associations utilised as inputs in the process of formulation and implementation of local public policies. This is assisted by the control exercised over the local political party. His position as head of the electoral slate and subsequent reelection guarantees him control over the party.

The Mayor also exercises situational and administrative leadership: he understands the reality of the city and is capable of diagnosing the needs and coordinating the actors essential to the search for solutions. In this context, his principal talents consist of 1) interpreting public opinion and mobilising support, 2) having a vision of the public policies of the administrative apparatus in terms of their impact upon the electorate. The leadership he exercises over the directorial staff of the administration enables him to adapt its administrative factors to meeting citizen demands as identified by the Mayor (Arenilla, 2001).

In summary, three characteristics may be identified in the Mayor's leadership which, according to Ioannou (Ioannou, 1992), are: personal characteristics. Caballero is not limited by reality. He takes risks and tends to act on the margins of norms. He shows energy, self-confidence, and his capacity for hard work. He employs specific tactics and behaviour (by looking for alliances with other actors) that increase his political resources to pursue his objectives. To this effect, he mobilises resources and attempts to maximise his autonomy. He attracts political and administrative collaborators to his viewpoints. He is not bound by his status as Mayor, although he does use it to mobilise resources. His ability to seize opportunities is clear in terms of taking advantage of favourable situations. Finally, he operates in a favourable context because he enjoys legitimacy as a result of renewing his mandate as Mayor in various legislatures ${ }^{8}$.

Therefore, it is easy to discern that the governance model initiative comes from a strong Mayor ${ }^{9}$ with a majority in plenary sessions. Taken together, the political impulse and legislative majorities are essential conditions for strengthening 
leadership as a guarantee of success in addition to citizen mobilisation, and inclusion of the most pressing social and economic problems in the political agenda.

\section{Public Management Innovations: Interaction of Councillors and Local Managers}

The governance process in the city of Alcobendas has a correlative: the modernisation of its administrative apparatus. One of the objectives of the local government team is to guarantee its re-election that obliges politicians to be receptive in order to identify and satisfy the needs of the local civil society. As a priority, this requires establishing the mechanisms for relations with citizens in general. While the key instruments in this relation are periodic elections, importance must also be given to channels for citizen participation, a decentralised political and administrative organisation being in touch with citizens, public policies aimed at satisfying the citizens' needs, and to strategic planning and communication with citizens. Furthermore, it is necessary to ensure local economic development and, consequently, an innovative interaction with the market. Here, the instruments for relations are public-private agreements on the development of construction projects in the city, and collaboration with the private sector in implementing local public policy aspects.

With regard to citizens, the relations between the administrative apparatus and civil society are based on the provision of high-quality public services. The necessary instruments for this are an increase in supply and quality of public services, bringing these services closer to citizens through decentralised service delivery, participation in service design and even in public service co-production or provision by citizens. To this end, the Mayor appoints a team of councillors or political representatives in close connection with public managers and technical specialists responsible for designing local policies. This interaction of political (councillors) and managerial leadership (professional and technical specialists) facilitates the efficient organisational change strategy.

\subsection{The Relationship between Elected Representatives and Directors and Specialist Technical Staff}

To facilitate joint work between politicians and managers, the Management Centre is created as a special administrative organ for the decentralised service management of planning, coordination, and organisation. This Management Centre is presided over by the Mayor, while the members of the Municipal Commission of Government act as committee members. 
The objective of the Management Centre creation is to develop and implement a new management culture on the basis of the differentiated organisation far removed from the bureaucratic culture. It is a unit with the capacity to coordinate and, consequently, to strengthen the strategic capacity of implementation centres, attempting to avoid the organisational fragmentation associated with the traditional system based on hierarchy. In order to control production and service provision on the part of distinct units, a System of Programming by Objectives (SPO) is set in motion which in turn consolidates the decentralised organisational structure. Both the SPO and decentralisation encourage an institutional learning process that leads to the introduction of a Strategic Plan in which citizens, associations, and local economic actors participate in decision-making associated with the matters of general interest to the city.

\subsubsection{The Management by Objectives System}

Implementing this instrument is an attempt to involve Area Directors in the management process in order to increase their responsibility with regard to political objectives. On the one hand, it is a mechanism of interaction that requires joint working between councillors and intermediate management. But on the other hand, the function of managers is understood to be that of motivating the personnel under their command, and involving them in the achievement of the Government team objectives. To this end, in the sphere of political guidelines, managers and specialist technical staff have a margin of proposing programmes and their objectives, results and budgets. Work is aimed at obtaining the results that are reached by consensus. Consequently, they enjoy legitimacy and enable rapid reaction in the case of non-fulfilment.

The implementation of this instrument revolves fundamentally around the creation of project teams, comprised of employees from diverse areas of administration or, in other words, organisation by projects. Thus, the coordination team agrees with each Programme Head on a concrete task.

\subsubsection{Strategic Planning}

By implementing a Strategic Plan for the city, the City Council of Alcobendas assumes leadership based on the coordination of the different actors that are able to take decisions and to contribute to their commitment to strengthening the city. The Strategic Plan serves as an educational instrument for planners and for citizens, and, in effect, has become a pedagogical instrument for cooperation. It makes actors aware of territorial solidarity so that the very process of elaborating the Strategic Plan is more important than actual results. In Alcobendas, the Strategic Plan allows defining new objectives that are compatible with the private objectives of actors. Similarly, it helps the diverse actors to design common 
strategies and identify common priorities. The Plan has an important educational effect: it educates participants with regard to the city. In this sense, it is an instrument to show the relationships and their position in the city structure. It also places emphasis on the process and not on the plan. To this end, it involves actors in the environment through a deliberative process that enables local elites to redefine the local public problems. The process of involving a set of actors with interests in the city so that they can identify political demands, and inviting them to outline the future design of the city further legitimate their relationship with the municipal institution.

\subsubsection{Decentralisation}

The organisational decentralisation model linked to coordination and planning has been a constant factor since the beginning of the 1980s when the growth of the municipal apparatus began. Decentralisation as an instrument of governance was introduced into the municipal agenda in 1984. It has remained there until today. It is certainly true that the objective is the creation of a highly decentralised public municipal sector. There is no doubt that the introduced decentralisation model has always been based on assigning responsibility to different areas. They enjoy different degrees of autonomy, resulting in increased contact and interactions between administration and its environment. At the same time, it intensifies and structures communication between administration and citizens by providing information. Decentralisation means that directors and managers are responsible for part of the financial, technical and administrative management of their areas, having determined degrees of autonomy for the management of human and instrumental resources, and acquiring responsibilities for the execution of local public programmes and policies, and similarly, for the results of financial, technical, human resource and administrative management.

\section{2 Relations between Specialist Technical Staff and Public Employees}

\section{2.1 Reorganisation of Processes and Procedures}

In Alcobendas, the reorganisation and innovation of administrative processes is the result of concentrating on the provision of services which citizens and administrative organisation take as a reference point for improving their performance. In this sense, they are tools for meeting citizens' needs and for improving the overall organisation performance by taking into account the involvement of suppliers and employees. The principal objective of the change in processes is to mobilise the creative potential of the greatest possible number of public employees. Process innovation is incrementally performed by evaluating organisational possibilities, and by agreeing on the design and implantation of 
innovations with the personnel who participate in the process through establishing ad hoc working parties that avoid its mere top-down extension.

\subsubsection{Quality}

In Alcobendas, the strategic and operative levels overlap in a continuous quality improvement process through operationalising the quality objectives defined by politicians on the basis of consultations in which directors, managers, and employees participate, and which are linked, inter alia, to organisational and costbased objectives. Similarly, quality indicators are defined (also according to interviews with citizens) on the basis of certain quality dimensions. Thus, an innovative approach to quality has been developed. Its ideas are framed by: 1) An orientation towards citizens' needs thereby providing continuous improvement of municipal services and products associated with different public policies. 2) An internal orientation by developing procedures for public employee participation in such a way that practically all employees, directors, and specialist technical staff are familiar with the concepts of quality. 3) Transversality and interrelation as defining characteristics in implantation of all the tools of quality, e.g., the Complaints System, Internet and Citizen Charter. Finally, it must be emphasized that innovations in each of the areas are complementary and coherent both with those undertaken in previous stages and with those undertaken in other areas. This means that the innovative actions reinforce each other, and thus the distinct activities become integrated in a package of policies.

All in all, the implementation of the above-mentioned instruments clearly shows shared leadership where collaboration between elected posts and managerial posts is continuously sought. The governance process in Alcobendas, while being promoted by the Mayor, is carried out by the nucleus of councillors who work with a group of public managers, forming a type of joint oligarchy on the basis of objectives shared between the managers and this group of councillors. This situation is encouraged by the autonomy of local government which shows that there is minimum intervention from other administrative levels in the day-to-day affairs of the local administration while, on the other hand, the penetration of the local pressure groups linked to economic interests is practically non-existent. This facilitates the administrative organisation control by political and bureaucratic elites in such a way that the Mayor and a group of councillors maintain control over local public policies.

Despite the institutional framework that favours the exercise of presidential leadership, the Mayor works with a government team that takes decisions collectively, although there is role differentiation between councillors. Although, from a formal point of view, all decisions are a collective responsibility, the nucleus of action has been formed so that, along with political leaders, some key 
bureaucrats at the head of certain services are important actors in the decisionmaking processes. They maintain close relations with political leaders. This derives from the organisation of seminars attended by councillors, managers, and specialist technical staff to exchange experience, which enables managers to internalise political objectives, thereby allowing councillors to identify their technical viability. In this sense, there is constant support from the managers to the elected councillors. This support is not based on partisan loyalty.

Moreover, the electoral success in the local sphere is influenced by the capacity of the municipal organisation which must not only define public problems, but also elaborate the necessary public policies through the organisational innovation capacity that facilitates the success of these policies. In Alcobendas, within the nucleus of councillors, the Councillor of Public Finance has control over the modernisation policy that attempts to influence all administrative units. Thus, the management leadership with power over expenditures is created. The success of reform stems not only from political leadership, but also from the management that has economic resources at its disposal.

Furthermore, the control taken by the Deputy Mayor signifies the introduction of rationalism into management. A search is made for the instruments tested in private organisations such as, inter alia, management by objectives, strategic planning, the redesign of procedures and quality ${ }^{10}$. All the modernisation proposals come from the nucleus of the Department of Public Finance whose role and legitimacy (on the basis of results) are progressively strengthened for the new proposal generation process.

Here, it is necessary to emphasise the important role played by the Deputy Mayor as Councillor of Public Finance who combines political leadership with a professional vision, dedicating part of his time to technical tasks. However, in percentage terms, the activity to which he dedicates most of his time is political activity, i.e., the search for information (from other public administrations, local civil society, a political party, etc.), providing information, and decision-making in conjunction with other actors.

In the Deputy Mayor's role, there is a certain isomorphism with other figures existing in countries with an Anglo-Saxon tradition, and in Northern European countries. Thus, in the sphere of medium-sized North American cities, there is a figure of the "City Manager" who is an administrative leader being in constant interaction with local politicians, and who has an important role in the local government process. He or she exercises an important influence on the elaboration and implementation of local public policies, while at the same time taking charge of the establishment of organisational designs as instruments that facilitate the achievement of the objectives of local public policies. 
The constant factor of the governance process in Alcobendas is collaboration between political leaders and municipal bureaucracy, although their role is different in the search for a common objective: the innovative behaviour of the entire municipal organisation in order to match its performance to the existing challenges. This collaboration is deliberately sought through joint activities such as holding joint seminars attended by councillors, managers and the Plenary Session members, discussing visions with managers, undertaking "political" evaluations complemented by manager evaluation, and political control over implementation processes.

\section{Conclusion}

This case analysis not only allows explaining the aspects regarding the structure of actors and their behaviour in the sphere of local government that influence the public decision-making processes and the transformation of the local administrative organisation, but it also allows understanding the evolution and consolidation of local governments from merely administrative bodies at other levels of government to political and administrative actors that generate administrative policies and actions of local interest through political leadership, particularly in medium-sized cities during a period of important political, social, and economic changes.

The patterns of interaction inseparable from the governance model are possible, provided that there is political leadership congruence, that is to say, the local political elites undertake leadership activities in order to constantly improve their capacity to relate to the administrative environment with which they interact. It is clear that the changes or transformations in administrative organisations simultaneously constitute a problem and an instrument of governance with regard to the central position that the administrative organisations occupy in the urban contexts of advanced societies. Thus, the administrative modernisation process is merely an instrument that facilitates city governance. At the same time, modernisation actions are the consequence of a governance regime, which in turn is facilitated by political leadership. Hence it follows that the administrative modernisation process cannot be the result of the application from within the organisation of managerial models, but must instead be derived from a governance form understood as a set of interactions between political and administrative elites and their environment. In a nutshell, the administrative modernisation process is a response derived from the demands of governance because in the urban sphere, political leadership, governance, and new local public management are intermingled in a dialectical relationship. 


\section{Notes}

${ }^{1}$ Case studies help to find the underlying principles explaining why a combination of specific activities, interacting with specific circumstances, lead to given results. Kaufman's (1960) research on the U.S. Forest Service stands as an example. To some extent, case study research has been recognised as a useful strategy for political and public management research, upon which scientifically valid knowledge can be generated (Agranoff, 1986; 1988; McGregor, 1993; Behn 1993; Lynnn, 1996, among others). Here, our inductive reasoning is based on the following qualitative data: a) 30 interviews with the Mayor, councillors from three different parties, local public managers, civil society leaders, local business representatives, and with the local newspaper editor; b) direct observation (the author has attended council meetings: both general and commission meetings, party meetings, and he has taken part in managerial processes such as strategic plan development); c) documents such as minutes of the council meetings, managerial proposals, and specialised local press.

2 This has been analysed on the basis of his statements to the press, radio appearances, and a personal interview. The Mayor is easy to understand, and his statements are clearly sincere.

3 “...I'm going to retire here as Mayor of Alcobendas..." (the Mayor).

4 "...we have a Mayor who loves having his own ideas, and this is good for us. We all plan and we all work thinking of things, the Mayor doesn't. Things occur to the Mayor, and he passes them on, and in the end, one out of every ten ideas works out, which is what constitutes some dynamics and the difference between this municipality and others..." (Town Planning Councillor, 1999-2003 legislature).

5 This visibility manifests itself in frequent public appearances. Every week, many hours are dedicated to meeting with citizens and interest representatives (associations and local businesses). On his agenda for the task time distribution, there is also an important institutional activity, dedicated to contacts and representation: "...The Mayor takes part in all the association movements, and, of course, in municipal actions. So, he is the man who continuously walks around the city to see what is wrong and what doesn't work..." (Local newspaper editor).

6 "...I believe that I have known from the beginning how to differentiate what is left-wing and what is right-wing from the viewpoint of the economic result. The principles of the right must always be defended, and we have to provide a social result. Well...it seems that those two options which seem antagonistic can converge...I believe that the results over a 20 -year period...converge social and economic elements ... towards the fundamental pillar developed in the first legislature...". (the Mayor).

7 "...the Mayor, being the person who works hardest, dedicates most of his time to the Town Hall. He is the person who also demands the most of ourselves, he demands convincingly, and in some way, he obliges you to give more than you are giving because you see that he is giving it to you, and, in addition, he is asking you for it..." (Town Planning Councillor).

8 "...According to the surveys of our Research Department and after several legislatures in power as Mayor and as Deputy Mayor, his image has been strengthened not only in being known as the Mayor who is logical, but also in recognition of his work that is now greater than 20 years ago, which isn't normal, is it? Remember how politicians fall out of favour. No, our Mayor hasn't lost favour. The surveys say so. The average citizen, the citizens of the whole city of Alcobendas still believe in the current Mayor (Town Planning Councillor).

9 "...the Mayor has been vital due to his authority (no decree authority) ... he is a more political than managerial Mayor, but he has been sensitive to these things and has supported them personally..." (Deputy Mayor). 

and Public Administration Modernisation: The Role of the Mayor and Councillors in a Spanish Municipality (1979-2007)

10 "...those of us here, at least in Alcobendas, none of us came from the public sector, and although we knew something, we knew how poorly the municipal government functioned..." (Deputy Mayor).

\section{References}

Agranoff, R. J. (1986) Intergovernmental management: Human Services Problem Solving in Six Metropolitan Areas (New York: State University of New York Press).

Agranoff, R. J. \& McGuire, M. (1998) A Jurisdiction Model of Intergovernmental management, Publius - The Journal of Federalism, 28(4), pp. 1-21.

Arenilla, M. (2001) Curso de Dirección y Gerencia Pública. Administración y Políticas Públicas (Sevilla: Instituto Andaluz de Administración Pública).

Bäck, H., Hubert, H. \& Magnier, A. (eds.) (2006) The European Mayor-Political Leaders in the Changing Context of Local Democracy (Wiesbaden: VS Verlag).

Behn, R. D. (1993) Case-Analysis Research and Managerial Effectiveness: Learning How to Lead Organisations on Sand Dunes, In: Bozeman, B. (ed.), Public Management (San Francisco: Jossey Bass), pp. 40-54.

Benington, J. (1998) On local governance, Paper presented at the Conference on local governance (19 March 1998), Economic and Social Research Council (ESRC), Exeter.

Berg, R. and Nirmala, R. (eds) (2005) Transforming Local Political Leadership (Houndsmill. Palgrave MacMillan).

Bowers, J. \& Wilbur C.R. (eds.) (2000) Governing Middle-Sized Cities: Studies in Mayoral Leadership (Boulder, CO: Lynnie Rinner Publishers).

Brugué, Q. \& Gomá, R. (1988) Gobierno Local. De la nacionalización al localismo y de la gerencialización a la politización, in: Brugué, Q. \& Gomá, R. (eds.) Gobiernos locales y politicas públicas: bienestar social, promoción económica y territorio (Barcelona: Ariel) pp. 15-35.

Canales, J.M. (2001) Gobernabilidad y Gestión Pública, In: Olias, B. (ed.) La Nueva Gestión Pública (Madrid: Prentice Hall), pp. 35-48.

Copus, C. (2006) Leading the Localities: Executive Mayors in English Local Governance (Manchester: Manchester University Press).

Drake, F. (1995) Political Leadership and European Integration: The case of Jacques Delors, West European Politics, 18(1), pp. 140-160.

Flanagan, R. M. (2004) Mayors and the Challenge of Urban Leadership (Lanham, MD: University Press of America).

Gissendanner, S. (2004) Mayors, Governance Coalitions and Strategic Capacity-Drawing Lessons from Germany for Theories of Urban governance, Urban Affairs Review, 40(1), pp. 44-77.

Gleason, B. (1970) Daley of Chicago (New Cork: Simon and Schuster).

Haus, M. \& Seeting, D. (2006) Local Democracy and Political Leadership: Drawing a Map, Political Studies, 54(2), pp. 267-288.

Iannou, A. (1992) Public Sector Entrepreneurship. Policy and Process Innovators, doctoral dissertation (London: University of London).

John, P. \& Cole, A. (2000) Political leadership in the new urban governance, In: Pratchett, L. (ed.) Renewing local democracy? The modernisation agenda in British local government (London: Frank Cass).

Kessner, T. (1989) Fiorello H. La Guardia and the Making of Modern New York (New York: MaGraw Hill).

Le Gales, P. (1995) Du gouvernement de villes a la gouvernance urbaine, Revue Francaise de Science Politique, 45 (1), pp. 57-95. 
Lynn, L. E. (Jr) (1996) Public Management as Art, Science and Profession (Chatam, N.Y.: Chatam House).

McGregor, E. B. (1993) Toward a Theory of Public Management Success, In: Bozeman, B. (ed.) Public Management (San Francisco, Jossey Bass).

Maxwell, J. A. (1996) Qualitative Research Design - An interactive Approach (Thousands Oaks, CA: Sage).

Nalbandian, J. (1999) Facilitating Community, Enabling Democracy: New Roles for Local Government Managers, Public Administration Review, 59(3), pp. 654-662.

Pfeffer, J. (1992) Managing with power (Boston: Harvard University Press).

Pratchett, L. (1999) Citizens and local government, Public Administration, 77(1), pp. 731-749.

Pressman, J. L. (1972) Preconditions of Mayoral Leadership, American Political Science Review, 66(2), pp. 731-749.

Putnam, R. (1993) Making Democracy Work. Civic Traditions in Modern Italy (Princeton: Princeton University Press).

Skelcher, C. (2005) Jurisdictional Integrity, Polycentrism, and the Design of Democratic Governance, Governance: An International Journal of Policy, Administration and Institutions 18(1), pp. 89-110.

Stoker, G. (1998) Governance as theory: five propositions, International Social Science Journal, 50(1), pp. 17-28.

Svara, J. (1990) Official leadership in the city (Oxford: Oxford University Press).

Svara, J. H. (ed.) (2009) The Facilitative leader in City Hall: Re-examining the Scope and Contributions (Boca Raton, FL: CRC Press). 